\title{
New species of caddisflies with bipectinate antennae from Cretaceous Burmese amber (Insecta, Trichoptera: Odontoceratidae, Calamoceratidae)
}

\author{
Wilfried WICHARD ${ }^{1}$, Marianne ESPELAND ${ }^{2, *}$, Patrick MÜLLER ${ }^{3} \&$ Bo WANG $^{4}$ \\ ${ }^{1}$ Institute of Biology and its Didactics, University of Cologne, \\ Herbert Lewinstrasse 2, 50931 Köln, Germany. \\ ${ }^{2}$ Arthropoda Department, Zoological Research Museum Alexander Koenig, \\ Adenauer-Allee 160, 53113 Bonn, Germany. \\ ${ }^{3}$ Friedhofstraße 9, 66894 Kashofen, Germany. \\ ${ }^{4}$ State Key Laboratory of Palaeobiology and Stratigraphy, Nanjing Institute of Geology and \\ Palaeontology and Center for Excellence in Life and Paleoenvironment, Chinese Academy of \\ Sciences, 39 East Beijing Road, Nanjing 210008, China. \\ *Corresponding author: M.Espeland@leibniz-zfmk.de \\ 1Email: Wichard@uni-koeln.de \\ 33Email: pat14789@web.de \\ [4Email: bowang@nigpas.ac.cn

\footnotetext{
${ }^{1}$ urn:1sid:zoobank.org:author:1E8601B2-A8F8-44A6-B185-4FB0B2E5219E

${ }^{2}$ urn:1sid:zoobank.org:author:00D6F9F9-3902-4A8B-846F-720AB32922A6

${ }^{3}$ urn:1sid:zoobank.org:author:CFA297B2-35D2-4C05-8F60-D73EBF620B5A

${ }^{4}$ urn:1sid:zoobank.org:author:7CBE9A76-16C4-4D6D-9B4D-B2BEC000ADDF
}

\begin{abstract}
Three new fossil species from Burmese amber are described, one clearly in family Calamoceratidae, the other two in the highly variable family Odontoceridae. The family Odontoceridae contains 18 disparate genera, but there are no good diagnostic characters, which makes it difficult to place fossil taxa in this family. We here offer a revised diagnosis for the family, highlighting the lack of good diagnostic characters, and the need to use sets of characters to place (extinct) taxa in this family. On this taxonomic basis we describe two new species in the hitherto monotypic fossil genus Palaeopsilotreta Wichard \& Wang, 2017 (Odontoceridae), Palaeopsilotreta burmanica sp. nov. and P. cretacea sp. nov., redescribe the type species based on additional information, and describe features of the female, based on two specimens, one of which is embedded adjacent to a male identified as P. xiai. Males of Palaeopsilotreta bear bipectinate antennae; the antennae of the females are simple and filiform. Similarly, bipectinate antennae are present in the third species we describe, Bipectinata orientalis gen. et sp. nov., which otherwise lacks the character combinations associated with the Odontoceridae, but clearly can be assigned to the family Calamoceratidae.
\end{abstract}

Keywords. Amber inclusion, Mid-Cretaceous, Myanmar, freshwater, aquatic insects.

Wichard W., Espeland M., Müller P. \& Wang B. 2020. New species of caddisflies with bipectinate antennae from Cretaceous Burmese amber (Insecta, Trichoptera: Odontoceratidae, Calamoceratidae). European Journal of Taxonomy 653: 1-17. https://doi.org/10.5852/ejt.2020.653 


\section{Introduction}

Trichoptera Kirby, 1815 in Burmese amber have been shown to include several morphological features not present in extant species (Wichard \& Wang 2017; Wichard et al. 2018). The three new species of fossil caddisflies described here are here assigned to two separate families, Odontoceridae Wallengren, 1891 and Calamatoceridae Ulmer, 1905, despite sharing one striking autapomorphy, namely bipectinate antennae, not found in any extant taxa. Odontoceridae comprises 15 extant genera and 3 extinct genera. One extant genus, Marilia Muller, 1880 and two of the extinct genera, Electrocerum Ulmer, 1912 and Electropsilotes Ulmer, 1912, are known from Eocene Baltic amber (Ulmer 1912; Wichard 2009). The other extinct genus, Palaeopsilotreta Wichard \& Wang, 2017, is known from mid-Cretaceous Burmese amber. The fossil species Calamodontus grandaevus Botosaneanu \& Wichard, 1983 from Taimyr amber in Siberia and Phenacopsyche vexans Cockerell, 1909 from the Florissant Formation in Colorado, each possibly belonging to the family Odontoceridae, are based only on wing fragments and cannot be associated with Odontoceridae with certainty.

Both adults and larvae of odontocerids are morphologically varied, and finding reliable diagnostic characters for the family, as well as separating Odontoceridae and the proposed closest relative, Philorheithridae Mosely, 1936, have been proven difficult (Wiggins 1996; Oláh \& Johanson, 2010). A close relationship between these families has been found in the most recent molecular phylogenetic studies based on extant taxa, but is never very well supported (Malm et al. 2013; Kjer et al. 2016; Johanson et al. 2017; Thomas et al. 2020). Both Kjer et al. and Malm et al. found Odontoceridae to be non-monophyletic, but the support was low, and the studies only included one odontocerid genus in common, making comparisons difficult. A new, more comprehensive molecular study shows Odontoceridae to be a well-supported monophyletic group, but not all genera are included (Frandsen et al. in prep.). The "post-anale" vein on the forewing first mentioned by Schmid $(1964,1980)$ is probably the only reliable synapomorphy uniting Odontoceridae and Philorheithridae (Weaver III et al. 2008). This feature, however, is not visible in any of the fossil taxa currently placed in Odontoceridae, making it more difficult to assign fossil species to these families. Good diagnostic characters for each family seem not to exist (Oláh \& Johanson 2011). Ocelli are absent in both families, and the spur formula is 2/4/4, with the exception of the Odontoceridae genera Phraepsyche Malicky \& Chantaramongkol, 2000 (1/4/4) and Baryphentus Burmeister, 1839 (0/2/2 to 2/2/2). Maxillary palpi are five-segmented in males, except for members of the genus Baryphentus, which have three-segmented palpi. Philorheithrids, in contrast, have three- to five-segmented palpi in the males. Most members of the Philorheithridae bear an apicomesal nodule (setal wart) on the first segment of the maxillary palpi, which is absent in odontocerids except for the genus Lannapsyche Malicky, 1989, where it is present in all species (Oláh \& Johanson 2010; Yang et al. 2017). Males of five of the nine philorheithrid genera additionally bear a pair of pilifers on the frons, which is not present in any odontocerids (Mosely \& Kimmins 1953; Schmid 1955). Philorheithrids, furthermore, have a thickened, sclerotized anal lobe present at the base of the forewing (Weaver III et al. 2008), which is absent in most Odontoceridae and, when present (e.g., Odontocerum Leach, 1815), is never extensively sclerotized or setose. The number of wing forks present in the wings of the male is stable in Philorheithridae (I, II, III, V), but varies from only I and II to I, II, III and V in Odontoceridae. The medial cell is always absent in both fore- and hindwings in both families. The discoidal cell in the male forewing is closed in both families, with the exception of some species in the odontocerid genus Marilia Müller, 1880. The thyridial cell is closed in Philorheithridae and most Odontoceridae, but open/absent in the genera Marilia, Psilotreta Banks, 1899, Palaeopsilotreta Wichard \& Wang, 2017, Pseudogoera Carpenter, 1933 and Cephalopsyche ArafinaArmitage \& Armitage, 2010 (Oláh \& Johanson 2011). Cu2 is reduced (never reaching wing margin) or absent in all Philorheitridae and all odontocerid genera except Palaeopsilotreta. R1 fuses with R2 in the male forewing in all philorheithrids, except Afrothreithrus Weaver, Gibon \& Chvojka, 2008 and one species of Philorheithrus Hare, 1910 (Henderson \& Ward 2006), whereas this state is very variable in 
Odontoceridae. The forewing termen is generally slightly concave in the Philorheithridae, but slightly convex in all odontocerids except Anastomoneura Huamantinco \& Nessimian, 2004, and some species of Marilia (concave) and Barypenthus (straight). Philorheithrids have two pairs of pronotal setal warts, while most odontocerids have one pair, except for the genera Madagocerum Olah \& Johanson, 2010, Lannapsyche and Phraepsyche, which also have two pairs. Odontocerids generally have a single, large, ovoid mesoscutellar setal wart, but Baryphentus has a pair of small setal warts on the mesoscutellum, which is the state also found in most Philorheithridae.

Based on geography, one might assign a confusing 'odontocerid/philorheithrid-like' species in Burmese amber to Odontoceridae instead of Philorheitridae, since the latter family has a typically Gondwanan distribution, and thus would not be expected in Burmese amber from the mid-Cretaceous, while Odontoceridae are more widely distributed. Sukatcheva \& Vassilenko (2011) presented a potential philorheithrid fossil wing fragment from Taimyr amber in Siberia, indicating that this family at some point possibly had a much wider distribution, which would nullify this possibility. These authors did not, however, mention on what characters this placement was based and, since there are no wing features unique to Philorheithridae (e.g., Weaver III et al. 2008) and since the pointed shape of the apex of the fossil wing is highly unusual, the placement of the fossil in this family is highly questionable.

We here describe two new species from Burmese amber in the fossil genus Paleaopsilotreta (Odontoceridae), with males that have bipectinate antennae, and discuss the difficulties of assigning fossil taxa to extant families. Furthermore, based on additional information, we revise the description of the type species of Paleaopsilotreta, and describe a possible female. Our third new species, which also has the remarkable bipectinate antennae, but otherwise does not conform with our diagnosis of Odontoceridae, is described in a new genus in the family Calamoceratidae.

\section{Material and methods}

The specimens are from an amber mine likely located near Noije Bum Village, Tanaing Township, Myanmar (Kania et al. 2015), but the exact locality is unknown. The age given by U-Pb dating of zircons from the volcanoclastic matrix of the amber is early Cenomanian $(98.8 \pm 0.6 \mathrm{Ma})$ (Shi et al. 2012), but the geological age of Burmese amber can be expected to be slightly older than the zircon date. The fossil specimens are embedded in small amber stones cut out from larger Burmese amber pieces. The adult insects are almost completely intact and visible in ventral and dorsal view. The male genitalia are flattened and, for some specimens, visible in ventral view only. The hindwings are partly covered by the somewhat distorted forewings. Some legs or parts of legs are missing. The head, thorax and abdomen show signs of decomposition and maceration. Antennae are complete or partially complete.

Photos were taken using a Leica stereo microscope M 420 Apozoom in combination with a Canon EOS $80 \mathrm{D}$, EOS utility software and the Zerene Stacker software. All images and figures were prepared with CorelDraw X4 and Adobe Photoshop CS4.

\section{Abbreviations}

The wing venation terminology in general follows Holzenthal et al. (2007):

I $=$ apical fork I

II $\quad=$ apical fork II

III $=$ apical fork III

IV $=$ apical fork IV

$\mathrm{V}=$ apical fork $\mathrm{V}$

$\mathrm{A}=$ analis

$\mathrm{Cu} 1=$ cubitus anterior 


$\mathrm{Cu} 2=$ cubitus posterior
$\mathrm{DC}=$ discoidal cell
$\mathrm{M}=$ media
$\mathrm{R}=$ radius

In male genitalia:

$\begin{array}{ll}\text { inf ap } & =\text { inferior appendages } \\ \text { cox } & =\text { coxopodite } \\ \text { har } & =\text { harpago } \\ \text { pr ap } & =\text { preanal appendage (cercus) } \\ \mathrm{X} \text { ap } & =\text { mesodorsal processes of tergum X }\end{array}$

The amber inclusions were made available by Patrick Müller and Bo Wang. Specimens in this study are deposited in the following repositories:

ZFMK = Zoological Research Museum Alexander Koenig, Bonn, Germany

NIGP $=$ Nanjing Institute of Geology and Palaeontology, Nanjing, China

\section{Results}

Order Trichoptera Kirby, 1815

Suborder Integripalpia Martynov, 1924

Family Odontoceridae Wallengren, 1891

\section{Revised diagnosis}

Ocelli absent; maxillary palpi 5-segmented in males (exception: Barypenthus, 3-segmented); without apicomesal nodule on first segment (exception: Lannapsyche, present); without pair of pilifers on the frons; spur formula 2/4/4 (exceptions: Phraepsyche 1/4/4, Barypenthus: 0/2/2 to 2/2/2); single, large, ovoid mesoscutellar setal wart (exception: Barypenthus, pair of small warts); one pair of pronotal setal warts (exceptions: Madagocerum, Lannapsyche, Phraepsyche, two pairs). In male forewing: termen slightly convex (exceptions: Barypenthus, straight; Anastomeura, slightly concave; Marilia, variable); wing fork IV never present (number of forks varying from two to four); discoidal cell always closed (exception: some species of Psilotreta); medial cell absent; thyridial cell absent or present; R1 and R2 sometimes fused; $\mathrm{Cu} 2$ reduced or absent, never reaching wing margin (exception: Palaeopsilotreta, reaching wing margin); post-anal vein present in all extant species (not visible in the fossils); anal lobe generally absent or, if present, reduced, but never extensively sclerotized or setose.

Genus Palaeopsilotreta Wichard \& Wang, 2017

\section{Type species}

Palaeopsilotreta xiai Wichard \& Wang, 2017, by monotypy.

\section{Diagnosis}

Palaeopsilotreta can be placed in the family Odontoceridae based on the following combination of characters: ocelli absent; spur formula 2/4/4; males with five segmented maxillary palps, first segment without apicomesal nodule, terminal segment not flexible or annulated; mesoscutum with a pair of ovoid setal warts, mesoscutellum covered by a single wart, large, dome-like and ovoid; presence of forewing forks I, II and V in both wings; discoidal cells closed, median and thyridial cells absent. It can be separated from other odontocerid genera by the $\mathrm{Cu} 2$ in the male forewings reaching the wing margin 
and not being reduced or absent as in all other genera, and by the unique combination of spur formula, number of wing forks in both wings of the males and the absence of a thyridial cell.

\section{Additions to description}

Antennae partially bipectinate, about as long as forewings. Rami of bipectinate flagellomeres slim and about as long as flagellomeres. Female antennae simple, not bipectinate. Maxillary palps 5 -segmented, terminal segment not flexible or annulate. Head ocelli absent; frontal, antennal and posterior setose warts present (Fig. 4E). Pronotum with 2 pronotal setose warts, mesoscutum bearing pair of small setose warts, mesoscutellum with one dome-shaped wart. In fore- and hindwings: forks I, II and V present. In male: media simple, unbranched, running to apical wing margin, or media branched in $\mathrm{M} 1+2$ and $\mathrm{M} 3+4$. In female: forewing media branched in $\mathrm{M} 1+2$ and $\mathrm{M} 3+4$. Discoidal cells closed or open, medial and thyridial cells lacking. Tibial spurs: 2/4/4.

Palaeopsilotreta xiai Wichard \& Wang, 2017

Fig. 1

\section{Diagnosis}

The antennae of males with 10 to 13 bipectinate flagellomeres and last 8 flagellomeres simple, not bipectinate. In forewing: media simple, unbranched. In male genitalia: harpago apically with a crown of three or four short black spines. Palaeopsilotreta xiai is clearly distinguished from P. cretacea sp. nov. by the unbranched media in the forewings, in contrast to $P$. cretacea $\mathrm{sp}$. nov. which has the media branched in forewings. Furthermore, P. xiai is clearly distinguished from P. burmanica sp. nov. by the harpago which has a crown of short black spines at its distal end in contrast to the two stout apical spines of $P$. burmanica sp. nov.

\section{Material examined}

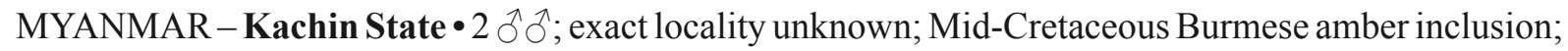
former Patrick Müller collection, BUB2571 and BUB3101; ZFMK-TRI000811, ZFMK-TRI000812.

\section{Additions to description}

The description and diagnosis of the holotype (Wichard \& Wang 2017) are supplemented with details from two further specimens.

Tibial spur formula 2/4/4 (short spur on front tibia not clearly visible on holotype).

On the apical cubital area in the forewing of the present male (ZFMK-TRI000811) more detail is visible than described in the holotype: Crossvein between $\mathrm{Cu} 1 \mathrm{~b}$ and $\mathrm{Cu} 2$, and crossvein $\mathrm{Cu} 2$ to lateral wing margin present.

The male genitalia of the holotype are only visible in ventral view. In the present male (ZFMKTRI000812) the genitalia are clearly visible through the hyaline wings in dorsal view (Fig. 1C-D): Segment X well developed, with bifurcate lobes; pair of subtriangular lobes protruding far forward and covering genital dorsally from above; lateral preanal appendages in dorsal view more digitiform, almost straight and slightly curved posteroventrally, apex rounded, each bearing single long needle; inferior appendages (gonocoxites) 2-segmented, coxopodites cone-shaped, about $2 / 3^{\text {rd }}$ the length of gonocoxites, harpagoes smaller, elongate and pencil-shaped, each ending in small crown consisting of 3 to 4 short, black spines. 

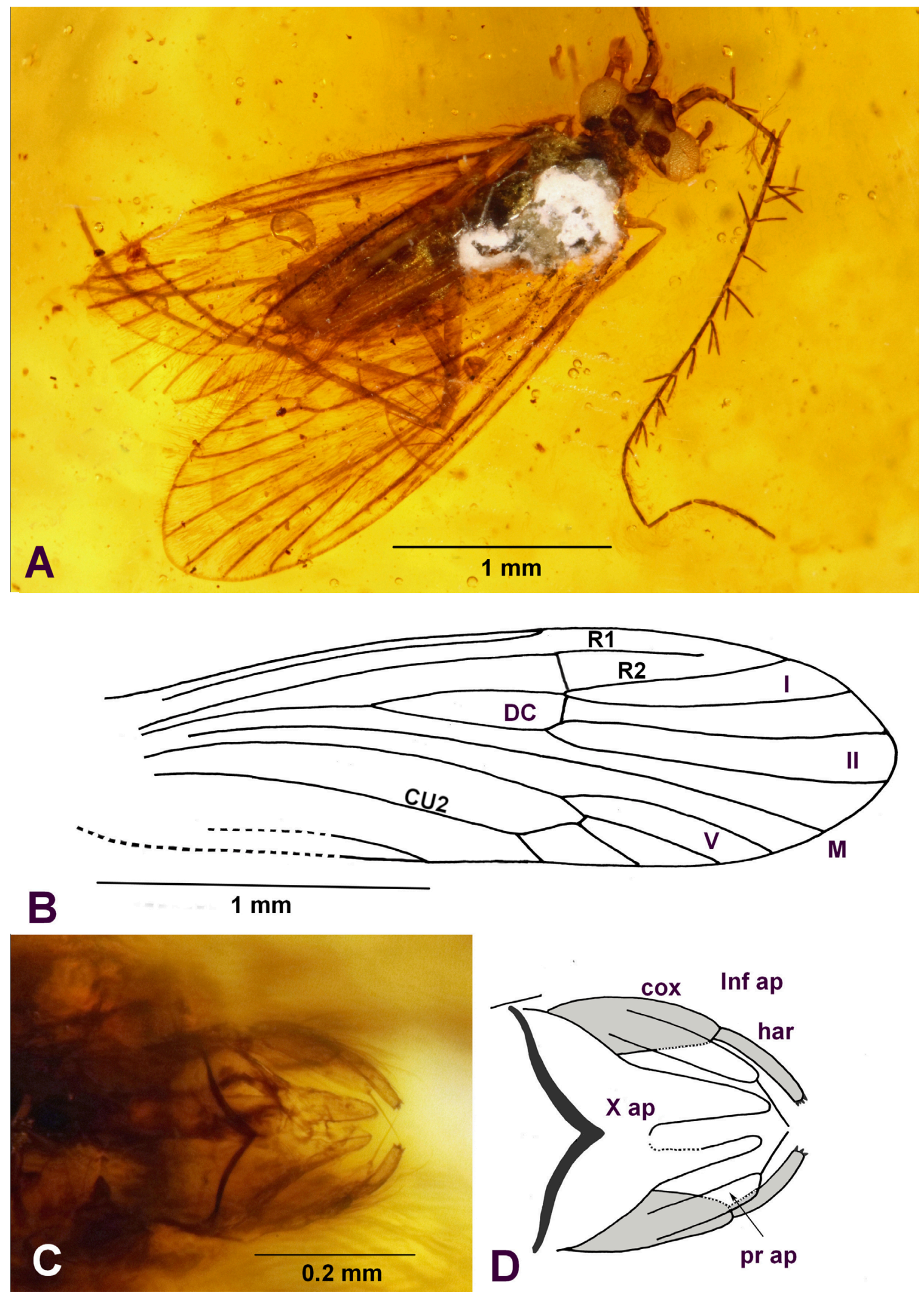

Fig. 1. Palaeopsilotreta xiai Wichard \& Wang, 2017. A. Male with bipectinate antennae in dorsal view (ZFMK-TRI000811). B. Drawing of a forewing. C. Male genitalia in dorsal view (ZFMK-TRI000812). D. Drawing of the male genitalia. 


\section{Palaeopsilotreta burmanica sp. nov. urn:1sid:zoobank.org:act:12B72DE2-74A4-4154-ACFF-6A3B2607DBEC}

Fig. 2, 4F

\section{Diagnosis}

Antennae in males with 10 bipectinate flagellomeres and last 2 flagellomeres simple, not bipectinate; in forewing, media simple, unbranched; in male genitalia, harpago apically with 2 clear, thorn-like, black spines. Palaeopsilotreta burmanica sp. nov. is clearly distinguished from P. cretacea sp. nov. by the unbranched media in forewings, $P$. cretacea sp. nov. has the media branched in forewings. Palaeopsilotreta burmanica sp. nov. is distinguished from P. xiai by the harpago having 2 strong thornlike, black spines at its apex; in P. xiai, the harpago has a crown of short black spines at its apex.

\section{Etymology}

Palaeopsilotreta burmanica sp. nov. is named after Burma, the old name of the country where the amber inclusion was found.

\section{Material examined}

\section{Holotype}

MYANMAR - Kachin State $-\widehat{O}$; exact locality unknown; Mid-Cretaceous Burmese amber inclusion; former Patrick Müller collection, BUB 2885; ZFMK-TRI000813. Body well preserved; forewing in dorsal view, hind wing covered dorsally by forewing. Antennae and legs present. Male genitalia visible in ventral view.

\section{Description}

HEAD. Light brown, laterally with prominent eyes. Antennae partially bipectinate, nearly as long as forewings. The bipectinate antennae (Fig. 2B) consist of long scapus, approximately twice as long as short pedicellus, followed by short flagellomeres as long as pedicellus, then 10 successive bipectinate flagellomeres and 2 simple terminal flagellomeres without bipectinate rami. Rami originating at base of each bipectinate flagellomere slender, about as long as flagellomere. Maxillary palps 5-segmented, terminal segment not flexible or annulate; labial palps 3-segmented (Fig. 4F). Head with ocelli absent, setose warts present: pair of small, ovoid interantennal setose warts, pair of postantennal (anterior) setose warts and pair of large, ovoid posterior setose warts. Pro- meso- and metanotum and their setose warts destroyed.

Forewings (Fig. 2C). Light brown, apically rounded, about $2.5 \mathrm{~mm}$ in length. Vein R1 running towards wing margin but turning slightly to fork R2 without reaching it. Forks I and II present; discoidal cell open, crossveins not visible. Open DC significantly shorter than forks I and II. Media simple, running to apical margin, unbranched into $\mathrm{M} 1+2$ and $\mathrm{M} 3+4$. Medial and thyridial cells absent. $\mathrm{Cu} 1$ running straight, apically bifurcated into fork $\mathrm{V}$; at the fork junction oblique crossvein to $\mathrm{M}$. $\mathrm{Cu} 2$ simple, apically crossvein to $\mathrm{Culb}$ and another crossvein to lateral wing margin. Anal veins complete. Hindwings light brown, dorsally covered by forewings, smaller than forewings, about $2 \mathrm{~mm}$ long. Radius R1 vein slightly thickened. Forks I, II and V visible, as well as media $\mathrm{M}$ and cubitus $\mathrm{Cu} 2$.

TiBiAL SPURS. 2/4/4.

MALE GENITALIA. Visible only in ventral view (Fig. 2D-E): inferior appendages (gonocoxites) 2-segmented, with coxopodiites and harpago clear and characteristic. Coxopodites broad and scalelike, longer than harpago, which is thin and pen-shaped, slightly curved towards middle of genital area, with 2 thorn-like black spines at apex. Preanal appendages and lobes of segment $X$ not clearly visible, concealed by lower appendages; details of phallic apparatus not sufficiently well preserved. 

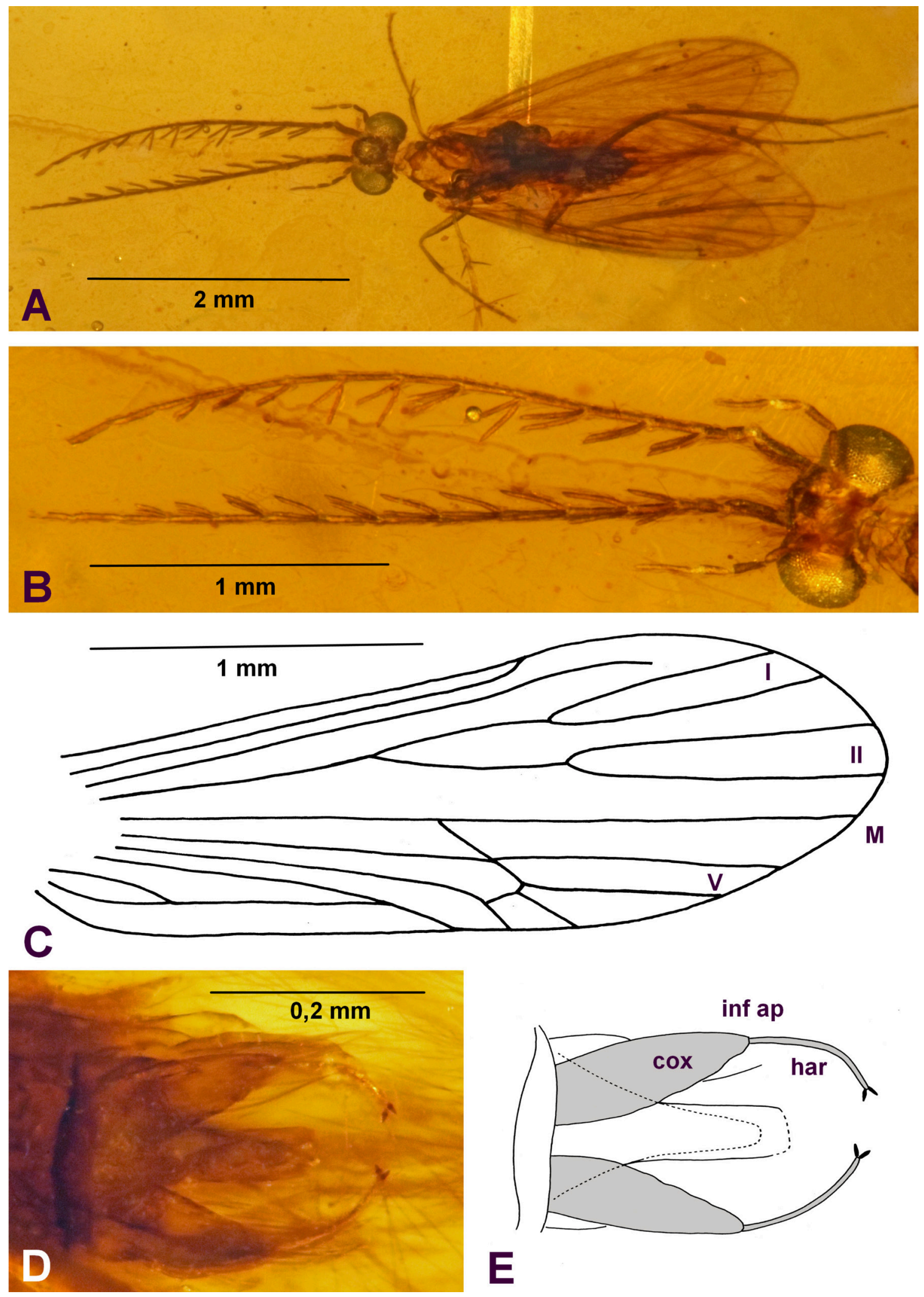

Fig. 2. Palaeopsilotreta burmanica sp. nov. (ZFMK-TRI000813) A. Holotype male in dorsal view. B. Head with maxillary palps and bipectinate antennae. C. Drawing of a forewing. D. Male genitalia in ventral view. E. Drawing of the male genitalia. 


\section{Palaeopsilotreta cretacea sp. nov. \\ urn:lsid:zoobank.org:act:DD288746-197D-4F8E-A45E-75D1330D1C45}

Fig. 3

\section{Diagnosis}

Antennae of males with 12 bipectinate flagellomeres and last two flagellomeres simple, not bipectinate. In male forewing, media branched in $\mathrm{M} 1+2$ and $\mathrm{M} 3+4$. In male genitalia, harpago apically with two clear thorn-like black spines. Palaeopsilotreta cretacea sp. nov. is clearly distinguished from P. xiai and $P$. burmanica sp. nov. by the branched media in forewings and by the harpago at an angle of $90^{\circ}$ to the coxopodite. Palaeopsilotreta xiai and P. burmanica sp. nov. have the media unbranched, and the harpago and coxopodite form a straight unit.

\section{Etymology}

Palaeopsilotreta cretacea sp. nov. is named for the geological age of the amber.

\section{Material examined}

\section{Holotype}

MYANMAR - Kachin State - Oे $^{\text {; }}$ exact locality unknown; Mid-Cretaceous Burmese amber inclusion; former Patrick Müller collection, BUB 2883; ZFMK-TRI000814. Body well preserved; forewing in dorsal view, hind wing covered dorsally by forewing. Antennae and legs present. Male genitalia visible in ventral view.

\section{Description}

HEAD. Light brown. Antennae partially bipectinate, consisting of long scapus, short pedicellus, and first flagellomere as long as pedicellus, both together about as long as scapus, followed by 12 successive bipectinate flagellomeres, and, finally, 2 simple flagellomeres without rami (Fig. 3B). Antennae about as long as forewings. Maxillary palps 5-segmented and labial palps 3-segmented, their terminal segments not flexible or annulate. Head dorsal ocelli absent, probably with interantennal, postantennal and posterior setose warts, but not well preserved and hard to recognize; scutum slightly macerated, scutellum shows single dome-shaped, large, ovoid wart.

Forewings (Fig. 3C). Light brown, translucent, $2.6 \mathrm{~mm}$ long. Radius R1 running straight to apical wing margin. Forks I and II of Rs present, sessile, branching at same level. Discoidal cell closed by crossveins, DC smaller, about half as long as fork I, fork II. Media branching into M1+2 and M3+4. Fork M longer than fork I and fork II, reaching up to half length of discoidal cell. Medial and thyridial cells absent. Cu1 running straight, apically bifurcated into fork $\mathrm{V}(\mathrm{Cu} 1 \mathrm{a}-\mathrm{Cu} 1 \mathrm{~b})$; $\mathrm{Cu} 2$ simple, not forked, so far as visible, probably with crossvein to $\mathrm{Cu} 1 \mathrm{~b}$. Anal veins probably complete. Hindwings light brown, translucent, relatively narrow, smaller than forewings, about $2.1 \mathrm{~mm}$ long, so far as visible, venation probably similar to forewing venation. Radius R1 straight, forks I, II present; M probably simple, without fork; Cu1 with relatively long fork $\mathrm{V}, \mathrm{Cu} 2$ simple. [Generally, crossveins in hyaline wings are difficult or impossible to detect].

TiBIAL SPURS. 2/4/4.

Male Genitalia. Visible only in ventral view (Fig. 3D-E): Inferior appendages (gonocoxites) 2-segmented. Coxopodites strong and slightly angular, broad at base, tapering towards apex, slightly curved towards genital centre, flanks more curved mesally than laterally. Harpago almost at right angle to coxopodites, directed centrad, rod-shaped, black, less than $1 / 3$ as long as coxopodites and much smaller in volume; apical end of harpago not clearly visible. Segment X apparently covering central phallic apparatus dorsally with 2 oblong scales. Lateral preanal appendages long, slightly bent inward. 

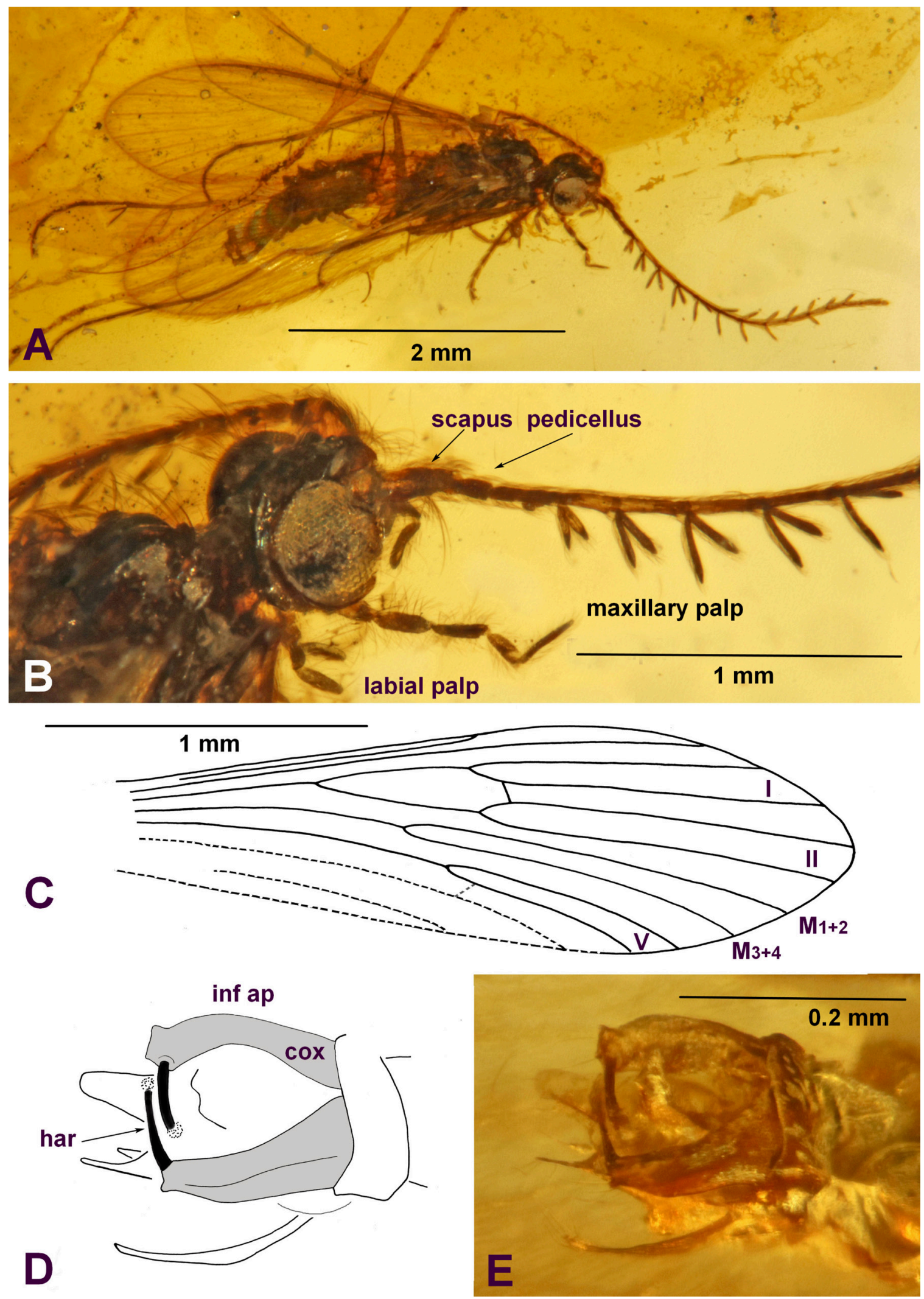

Fig. 3. Palaeopsilotreta cretacea sp. nov. (ZFMK-TRI000814) A. Holotype male in dorsal view. B. Head with bipectinate antennae, maxillary palps and labial palps. C. Drawing of a forewing. D. Drawing of the male genitalia. E. Male genitalia in ventral view. 


\section{Female of genus Palaeopsilotreta}

Fig. 4A-D

\section{Material examined}

MYANMAR - Kachin State - 2 q ; exact locality unknown; Mid-Cretaceous Burmese amber inclusions; former Patrick Müller collection, BuB2572a and BuB2572b; ZFMK-TRI000815, ZFMKTRI000816.

\section{Remarks}

In a small piece of Burmese amber (ZFMK-TRI000815) two caddis flies, a male and a female, are embedded $1 \mathrm{~mm}$ apart (Fig. 4A). The male is identified as Palaeopsilotreta xiai (antennae with 12 bipectinate flagellomeres plus 8 last flagellomeres simple; in forewing, media simple, unbranched); the nearby female seems most likely to be the same species as the male.

In addition to morphological similarities, there is a clear sexual dimorphism. The female has simple, non-pectinate antennae. Furthermore, the forewing venation is different; the female has the media forked into M1+2 and M3+4 whereas the media in male Palaeopsilotreta xiai is simple, unbranched. Since we cannot be sure that these females belong to $P$. xiai even though one of them was found in close proximity to a male, we here leave both unplaced in the genus Palaeopsilotreta.

\section{Description}

Female embedded in a further separate piece of amber (ZFMK-TRI000816). Body and wings light brown (Fig. 4B).

HEAD. Antennae simple, not bipectinate, consisting of long scapus, short pedicellus, first flagellomere as long as pedicellus, both together about as long as scapus, followed by about 26 successive simple flagellomeres without rami. Antennae about as long as forewings. Maxillary palps 5-segmented and labial palps 3-segmented, their terminal segments not flexible or annulate. Head with ocelli absent, setose warts on head and thorax badly preserved and macerated.

FoREWINGS. $3.4 \mathrm{~mm}$ in length (Fig. 4D). Radius R1 running towards wing margin, but turns slightly towards fork R2 without reaching it. Forks I and II of Rs present, sessile, branching at same level. Discoidal cell probably closed by crossveins. [Generally, crossveins in wings embedded in amber often difficult or impossible to detect.] DC smaller, about half as long as fork I, fork II. Media branching into $\mathrm{M} 1+2$ and $\mathrm{M} 3+4$. Fork M longer than forks I, II and V, reaching up to half the length of discoidal cell. $\mathrm{Cu} 1$ running straight, apically bifurcated into fork $\mathrm{V}(\mathrm{Cula}-\mathrm{Cu} 1 \mathrm{~b})$; crossvein $\mathrm{m}$-cu present, therefore thyridial cell present. $\mathrm{Cu} 2$ simple, unforked, with a crossvein to $\mathrm{Cu} 1 \mathrm{~b}$. Anal veins probably complete. Hindwings covered by forewings. In ventral view not clearly visible.

TiBIAL SPURS. 2/4/4.

Female terminalia (Fig. 4 C). External structures much simplified, embedded and slightly twisted in amber, therefore difficult to interpret. 

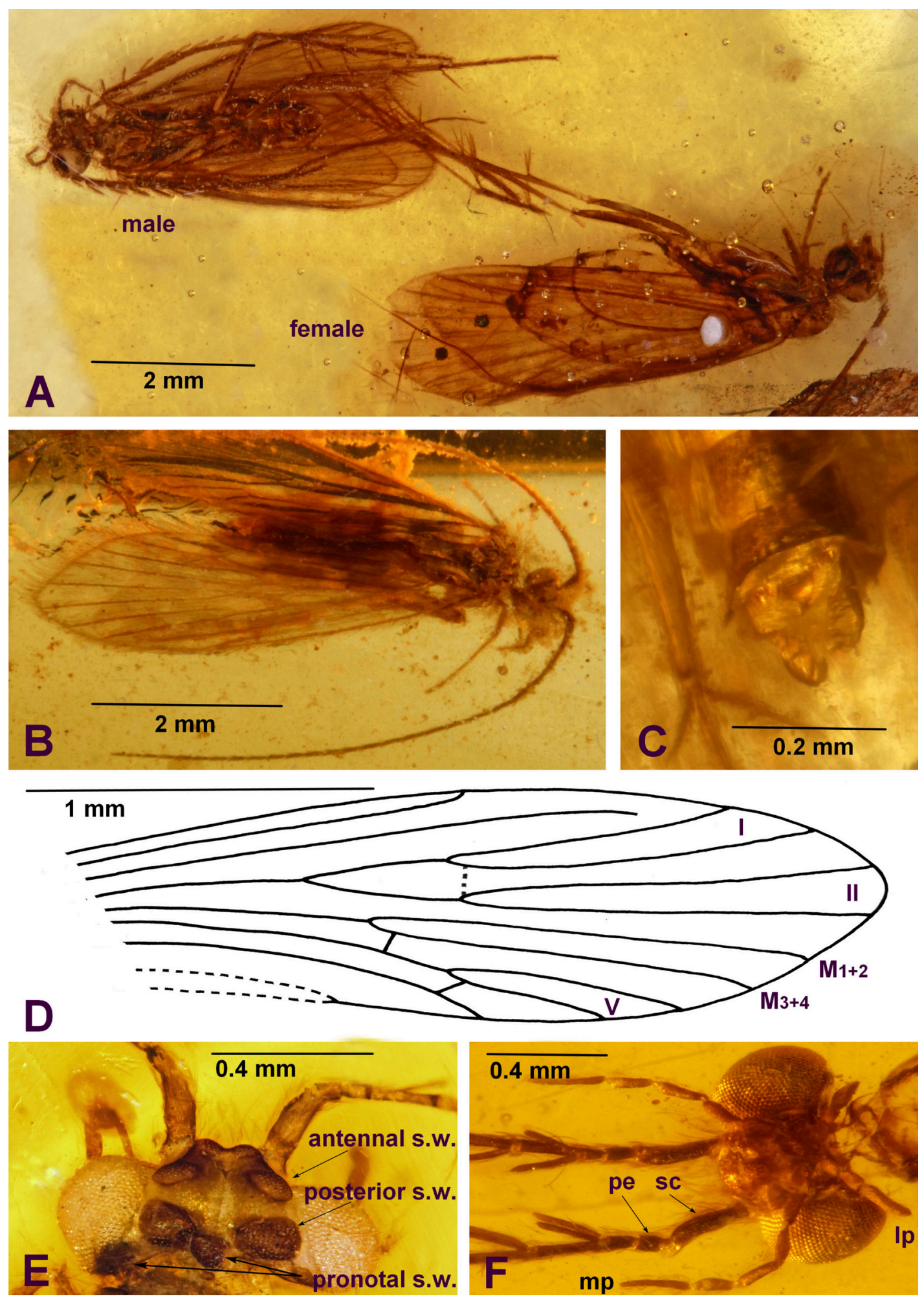

Fig. 4. Palaeopsilotreta xiai Wichard \& Wang, 2017. A. Male and possible female in one Baltic amber piece (ZFMK-TRI000815). B. Female with simple, filiform antennae in dorsal view (ZFMK-TRI000816). C. Female genitalia, as far as visible in cloudy amber (ZFMK-TRI000816). D. Drawing of female forewing. E. Head of male (ZFMK-TRI000811) in dorsal view with antennal, posterior and pronotal setose warts (s.w.). - F. P. burmanica sp. nov. (ZFMK-TRI000813), head of male with maxillary palps (mp), labial palps (lp) and basal bipectinate antennae with scapus (sc) and pedicellus (pe). 


\author{
Family Calamoceratidae Ulmer, 1905 \\ Genus Bipectinata gen. nov. \\ urn:1sid:zoobank.org:act:7C273977-F413-47A4-947F-60758591D2A0
}

\title{
Type species
}

Bipectinata orientalis gen. et sp. nov.

\section{Diagnosis}

The genus Bipectinata gen. nov. resembles the odontocerid genus Palaeopsilotreta, sharing the autapomorphy of bipectinate antennae, but is distinguished from Palaeopsilotreta by the shape of the rami of the bipectinate flagellomeres. In Palaeopsilotreta, the rami are uniformly slim and about as long as the flagellomeres; in Bipectinatagen. nov. , the thin rami gradually enlarge into a small club and are always longer than the flagellomeres. Furthermore, in Palaeopsilotreta the fore- and hindwing venation is characterized by the presence of forks I, II, and V and by the loss of forks II and IV, whereas in forewings of Bipectinata gen. nov. forks I, II, III, IV and V are present. In addition, in Palaeopsilotreta, the thyridial cell is absent, while it is closed in Bipectinata gen. nov. Based on the combination of wing venation, spur formula and 5-segmented maxillary palpi, we place this genus in the Calamoceratidae.

\section{Etymology}

The genus is named for its bipectinate antenna.

\section{Description}

Male antennae partially bipectinate, medially having 16 bipectinate flagellomeres, followed by 18 simple flagellomeres without rami. Maxillary palps 5-segmented, terminal segment not flexible or annulate. Ocelli absent. Forewing with forks I, II, III, IV, V; discoidal cell and thyridial cell closed, medial cell absent. Hindwing with forks I, II, II, V; discoidal, medial and thyridial cells absent. Tibial spurs: 2/4/4. Male genitalia with 2-segmented inferior appendages.

Bipectinata orientalis gen. et sp. nov.

urn:lsid:zoobank.org:act:988D3108-67F2-473D-85AB-E21A4E02DA46

Fig. 5

\section{Diagnosis}

See the corresponding diagnosis of the genus

\section{Etymology}

The species name describes the biogeographic region in which this new fossil species was found.

\section{Material examined}

\section{Holotype}

MYANMAR - Kachin State - ${ }^{\lambda}$; exact locality unknown; Mid-Cretaceous Burmese amber inclusion; NIGP172206.

\section{Description}

HEAD. Antennae about as long as forewings, partially bipectinate, first consisting of long scapus, short pedicellus and simple flagellomere longer than pedicellus, both together about as long as scapus; followed by 16 successive bipectinate flagellomeres and, finally, 18 simple flagellomeres without rami. 

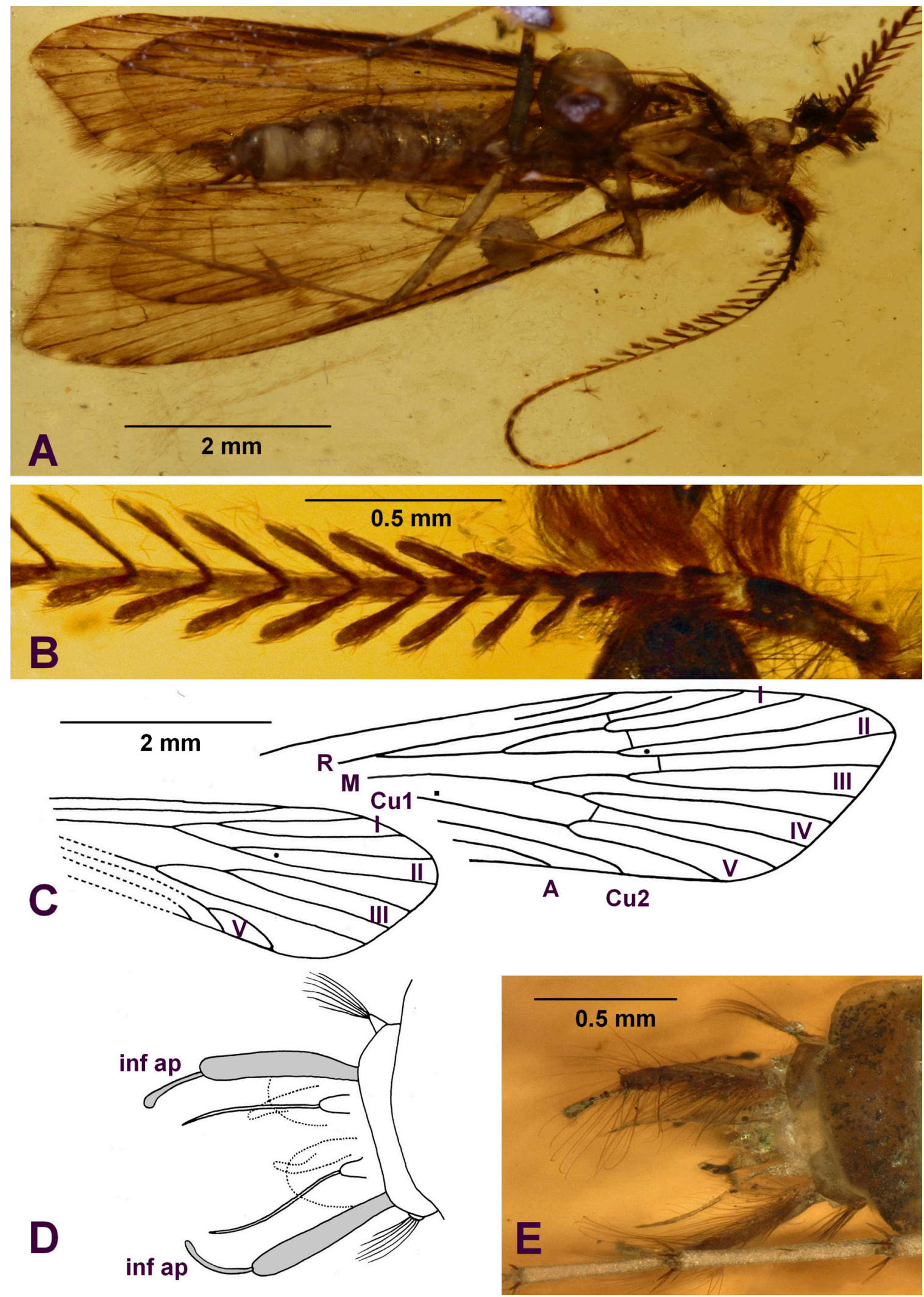

Fig. 5. Bipectinata orientalis sp. nov. (NIGP172206) A. Holotype male in ventral view. B. Bipectinate antennae with scapus, pedicellus and flagellomeres. C. Drawing of fore- and hindwings. D. Drawing of the male genitalia. E. Male genitalia in dorsal view. 
Rami originating on both sides at base of flagellomere, basally slender and gradually expanding towards rounded apex. Maxillary palps 5-segmented, labial palps 3-segmented, their terminal segments not flexible or annulate. Head dorsally with broad posterior setose warts, transverse, covered with single, long hairs; scutum densely haired, setose warts not visible, scutellum shows single dome-shaped, large, ovoid wart.

Forewings. Light brown, slightly translucent, $6 \mathrm{~mm}$ long. Radius R1 running straight to apical wing margin. Forks I and II of Rs present, sessile, branching at same level. Nygma at base of fork II. Discoidal cell closed by crossveins, about as long as its stem Rs. Media branching first into M1+2 and M3+4 and then forks III and IV, medial cell absent or open. Cul running straight, apically bifurcated into fork V (Cu1a-Cu1b); crossvein m-cu between Cu1a and M4, therefore thyridial cell present, very probably with nygma. Cu2 simple, not forked. Anal veins probably complete. Hindwings (Fig. 5C) light brown, translucent, smaller than forewings, about $4.5 \mathrm{~mm}$ long, Radius R1 straight, forks I, II present, fork II with nygma basally; discoidal cell absent or open. M branched in fork III and in M3+4. Cu1 with fork V, $\mathrm{Cu} 2$ simple. Crossveins not clearly visible, but indicated in forewings through fine, small hairs, running parallel to each other and forming 'staggered bridge' between longitudinal veins.

TiBIAL SPURS. 2/4/4.

MALE GENITALIA. Visible only in ventral view: Inferior appendages (gonocoxites) 2-segmented consisting of straight digitiform coxopodite and curved rod-shaped harpago, length ratio 3:1; harpago initially thin and gradually enlarging into small club. Pair of long needles situated between inferior appendages, slightly dorsally placed and curved medio-dorsad, sitting on slightly stronger pedestal. In ventral view central phallic apparatus is possibly covered by 2 membranous dorsal scales, probably derived from the Xth segment, and laterally flanked by 2 short parameres [phallic apparatus itself remains unclear].

\section{Discussion}

Burmese amber and its inclusions are nearly 100 million years old (Shi et al. 2012). The long geological time span corresponds to a sequence of around 100 million generations for univoltine insects and often complicates the taxonomic assignment of fossil species to modern higher taxa, e.g., to families. It cannot be expected that these fossil taxa share all diagnostic characters of families composed mainly of extant species. The presence of wing fork IV in the wings of males of Bipectinata orientalis gen. et sp. nov. precludes its placement in Odontoceridae and Philorheithridae. Fork IV is present in all Calamoceratidae and, as in Bipectinata gen. nov., the spur formula is 2/4/4 (in most species) and maxillary palpi are 5-segmented (in most species). Some calamoceratid species (e.g., in Anisocentropus McLachlan, 1863) also have closed discoidal and thyridial cells in combination with an open medial cell as found in Bipectinata gen. nov. Based on these characters, we therefore feel confident in placing Bipectinata gen. nov. in Calamoceratidae.

Based on the presence of five-segmented palpi, of only wing forks I, II and V in both wings (Philorheithridae have I, II, III, V), the spur formula being $2 / 4 / 4$ and the absence of the medial cell in combination with the closed discoidal cell, we can likewise assign the fossil genus Palaeopsilotreta to Odontoceridae, even though the $\mathrm{Cu} 2$ in male forewings is not reduced or absent as in the other congeners. Our revised diagnosis of the Odontoceridae highlights the lack of diagnostic characters and the need of sets of characters when placing (extinct) taxa in this family. Whether Odontoceridae, as currently recognized, is a monophyletic group, needs to be further investigated using more data and a dense taxon sampling. 


\section{Acknowledgements}

We are grateful to Alice Wells and Tobias Malm for their valuable comments on the manuscript. This research was supported by the Strategic Priority Research Program of the Chinese Academy of Sciences (XDA19050101 and XDB26000000), the Second Tibetan Plateau Scientific Expedition and Research (2019QZKK0706) and the National Natural Science Foundation of China (41622201 and 41688103).

\section{References}

Henderson I. \& Ward J.B. 2006. Four new species of the caddis genus Philorheithrus (Trichoptera: Philorheithridae) from New Zealand. Records of the Canterbury Museum 20: 21-33.

Holzenthal R.W., Blahnik R.J., Prather A.L. \& Kjer K.M. 2007. Order Trichoptera Kirby, 1813 (Insecta), Caddisflies. Zootaxa 1668: 639-698. https://doi.org/10.11646/zootaxa.1668.1.29

Johanson K.A., Malm T. \& Espeland M. 2017. Molecular phylogeny of Sericostomatoidea (Trichoptera) with the establishment of three new families. Systematic Entomology 42: 240-266.

https://doi.org/10.1111/syen.12209

Kania I., Wang B. \& Szwedo J. 2015. Dicranoptycha Osten Sacken, 1860 (Diptera, Limoniidae) from the earliest Upper Cretaceous Burmese amber. Cretaceous Research 52: 522-530.

https://doi.org/10.1016/j.cretres.2014.03.002

Kjer K.M., Thomas J.A., Zhou X., Frandsen P.B., Prendini E. \& Holzenthal R.W. 2016. Progress on the phylogeny of caddisflies (Trichoptera). Zoosymposia 10: 248-256.

https://doi.org/10.11646/zoosymposia.10.1.23

Malm T. Johanson K.A. \& Wahlberg N. 2013. The evolutionary history of Trichoptera (Insecta): A case of successful adaptation to life in freshwater. Systematic Entomology 38: 459-473.

https://doi.org/10.1111/syen.12016

Mosely M.E. \& Kimmins D.E. 1953. The Trichoptera (Caddis-Flies) of Australia and New Zealand. British Museum of Natural History, London. https://doi.org/10.5962/bhl.title.118696

Oláh J. \& Johanson K.A. 2010. Description of 33 new species of Calamoceratidae, Molannidae, Odontoceridae and Philorheithridae (Trichoptera), with detailed presentation of their cephalic setal warts and grooves. Zootaxa 2457: 1-128. https://doi.org/10.11646/zootaxa.2457.1.1

Oláh J. \& Johanson K. 2011. Description of a new endemic genus of Trichoptera from Madagascar (Odontoceridae). Acta Zoologica Academiae Scientiarum Hungaricae 57: 117-129.

Schmid F. 1955. Contributions à la connaissuance des Trichoptères néotropicaux. Mémoires de la Société vaudoise des Sciences naturelles 11: 117-160.

Schmid F. 1964. Contribution à l'étude des Trichoptères néotropicaux V. Tijdschrift voor Entomologie 107: 307-339.

Schmid F. 1980. Genera des Trichoptères du Canada et des Etats adjacents. Les insectes et arachnides du Canada 7. Direction de la recherche, Agriculture Canada, Ottawa.

Shi G., Grimaldi D.A., Harlow G.E., Wang J., Wang J., Yang M., Lei W., Li Q. \& Li X. 2012. Age constraint on Burmese amber based on U-Pb dating of zircons. Cretaceous Research 37: 155-163. https://doi.org/10.1016/j.cretres.2012.03.014

Sukatcheva I.D. \& Vassilenko D.V. 2011. Caddisflies from Chernovskie Kopi (Jurassic/Cretaceous of Transbaikalia). Zoosymposia 5: 434-438. https://doi.org/10.11646/zoosymposia.5.1.37

Thomas J.A., Frandsen P.B., Prendini E., Zhou X. \& Holzenthal R.W. 2020. A multigene phylogeny and timeline for Trichoptera (Insecta). Systematic Entomology. https://doi.org/10.1111/syen.12422 
Ulmer G. 1912. Trichopteren des Baltischen Bernsteins. Beiträge zur Naturkunde Preussens 10: 1-380.

Weaver III J.S., Gibon F.-M. \& Chvojka P. 2008. A new genus of Philorheithridae (Trichoptera) from Madagascar. Zootaxa 1825: 18-28. https://doi.org/10.11646/zootaxa.1825.1.2

Wichard W. 2009. Overview and Description of Trichoptera in Baltic Amber - Spicipalpia and Integripalpia. Verlag Dr. Kessel, Remagen-Oberwinter.

Wichard W. \& Wang B. 2017. A remarkable caddisfly with bipectinate antennae in Cretaceous Burmese amber (Insecta, Trichoptera). Cretaceous Research 69: 198-203.

https://doi.org/10.1016/j.cretres.2016.09.012

Wichard W., Espeland M. \& Wang B. 2018. Caddisflies with unusual hair-fans on the legs in Cretaceous Burmese amber (Insecta, Trichoptera). Palaeodiversity 11: 21-28. https://doi.org/10.18476/pale.11.a3

Wiggins G.B. 1996. Larvae of the North American Caddisfly Genera (Trichoptera). University of Toronto Press, Toronto. https://doi.org/10.3138/9781442623606

Yang L.-F., Yuan H.-Y. \& Morse J.C. 2017. Lannapsyche and Marilia species of China (Trichoptera: Odontoceridae). Zootaxa 4320: 81-99. https://doi.org/10.11646/zootaxa.4320.1.5

Manuscript received: 18 November 2019

Manuscript accepted: 11 February 2020

Published on: 27 May 2020

Topic editor: Christian de Muizon

Desk editor: Kristiaan Hoedemakers

Printed versions of all papers are also deposited in the libraries of the institutes that are members of the EJT consortium: Muséum national d'histoire naturelle, Paris, France; Meise Botanic Garden, Belgium; Royal Museum for Central Africa, Tervuren, Belgium; Royal Belgian Institute of Natural Sciences, Brussels, Belgium; Natural History Museum of Denmark, Copenhagen, Denmark; Naturalis Biodiversity Center, Leiden, the Netherlands; Museo Nacional de Ciencias Naturales-CSIC, Madrid, Spain; Real Jardín Botánico de Madrid CSIC, Spain; Zoological Research Museum Alexander Koenig, Bonn, Germany; National Museum, Prague, Czech Republic. 